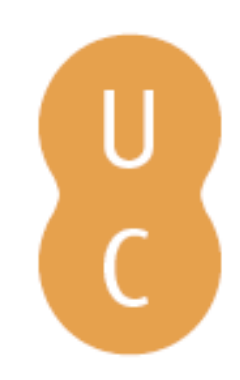

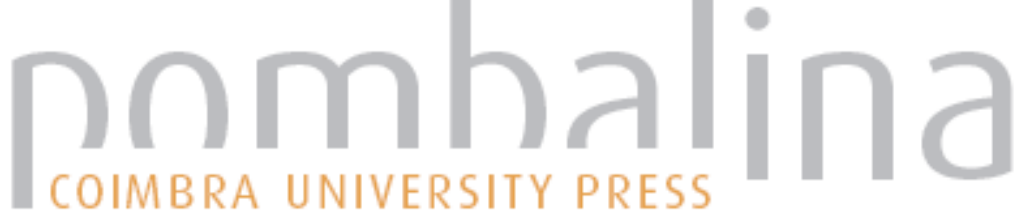

The effectiveness of suppression resources in large fire management in the US: a review
Autor(es):
Calkin, David; Katuwahl, Hari; Hand, Michael; Holmes, Tom
Publicado por: Imprensa da Universidade de Coimbra
URL
persistente:
URI:http://hdl.handle.net/10316.2/34196
DOI:
DOI:http://dx.doi.org/10.14195/978-989-26-0884-6_170
Accessed : $\quad$ 26-Apr-2023 12:18:00

A navegação consulta e descarregamento dos títulos inseridos nas Bibliotecas Digitais UC Digitalis, UC Pombalina e UC Impactum, pressupõem a aceitação plena e sem reservas dos Termos e Condições de Uso destas Bibliotecas Digitais, disponíveis em https://digitalis.uc.pt/pt-pt/termos.

Conforme exposto nos referidos Termos e Condições de Uso, o descarregamento de títulos de acesso restrito requer uma licença válida de autorização devendo o utilizador aceder ao(s) documento(s) a partir de um endereço de IP da instituição detentora da supramencionada licença.

Ao utilizador é apenas permitido o descarregamento para uso pessoal, pelo que o emprego do(s) título(s) descarregado(s) para outro fim, designadamente comercial, carece de autorização do respetivo autor ou editor da obra.

Na medida em que todas as obras da UC Digitalis se encontram protegidas pelo Código do Direito de Autor e Direitos Conexos e demais legislação aplicável, toda a cópia, parcial ou total, deste documento, nos casos em que é legalmente admitida, deverá conter ou fazer-se acompanhar por este aviso.

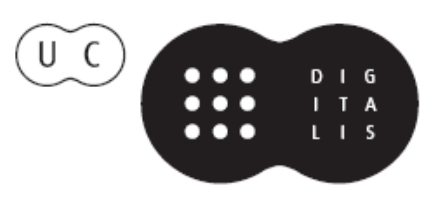




\section{ADVANCES IN}

Forest Fire

\section{RESEARCH}

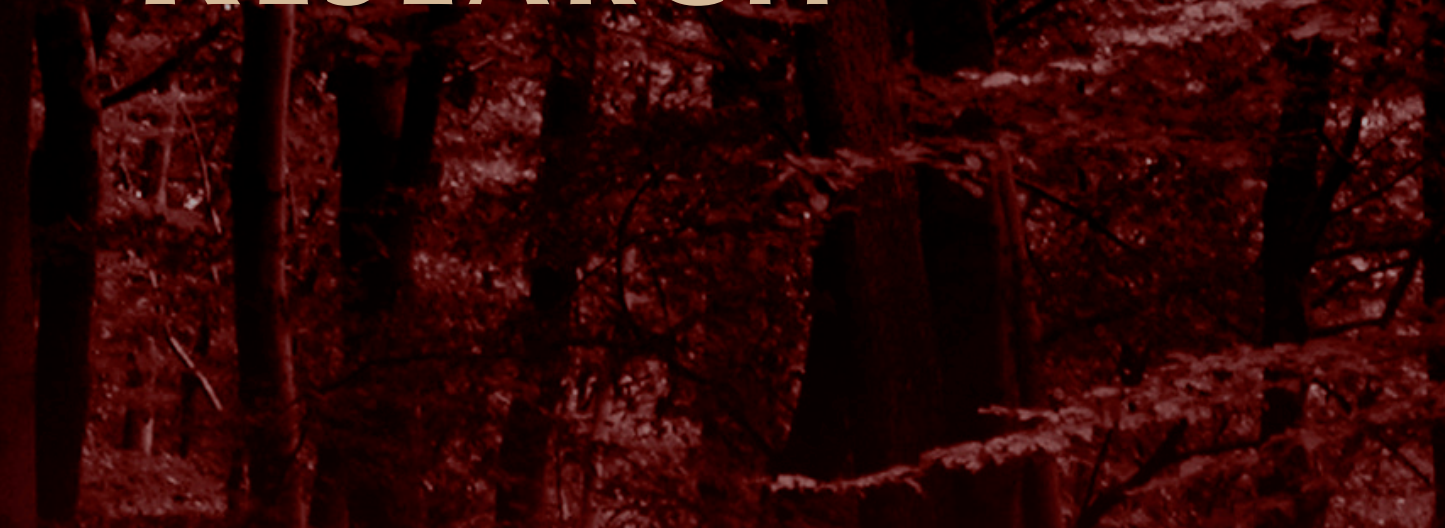

\section{DOMINGOS XAVIER VIEGAS}

\section{EDITOR}




\title{
The effectiveness of suppression resources in large fire management in the US; A Review
}

\author{
David Calkin $^{\mathrm{a}}$, Hari Katuwahl ${ }^{\mathrm{b}}$, Michael Hand ${ }^{\mathrm{a}}$, and Tom Holmes ${ }^{\mathrm{c}}$ \\ ${ }^{a}$ US Forest Service Rocky Mountain Research Station, Missoula, Montana, USA, decalkin@fs.fed.us \\ andmshand@fs.fed.us \\ ${ }^{b}$ University of Montana, Missoula, Montana, hkatuwahl@fs.fed.us \\ ${ }^{c}$ US Forest Service Southern Research Station, Research Triangle Park, NC, USA, \\ tholmes@fs.fed.us
}

\begin{abstract}
Wildfire management currently represents nearly 50 percent of the US Forest Service's total budget. In both 2012 and 2013 large fire suppression exceeded the Agency's budget allocations by over \$400 million (US\$). Despite the scale of this investment relatively little is understood about how suppression actions influence large wildfire spread and those conditions that ultimately lead to containment. There is considerable uncertainty in managing large wildfires including the quality of weather forecasts, complex environmental conditions, variation in the type and quality of suppression resources, and whether or not requested suppression resources will be assigned.

In this presentation we review several recent studies that attempt to understand how suppression actions influence fire progression of large wildland fires in the US. Finney et al. (2009) who established the critical importance of quiescent fire growth periods in achieving final fire containment. Holmes and Calkin (2013) used econometric analyses including Cobb-Douglas production functions and production possibility frontiers to examine the effect of different suppression resources and fire characteristics on daily reported fire containment. We extend the Holmes and Calkin (2013) analysis by focusing on geospatially delineated fire progression maps to identify how suppression resources and fire characteristics influenced the amount of fire perimeter that held on a given day. Additionally we review a small sample of large fires where field based data collection allows us to better understand the types of mission and relative efficiency and effectiveness of field based crews.

Despite these recent efforts, there remains limited understanding of suppression effectiveness. These results suggest that modelling large fire containment as a production process of fireline construction similar to traditional initial attack models is inappropriate. Improved understanding of large fire management effectiveness and efficiency will require spatially tracking individual resource assignments, activities, and tactics within the broader suite of fire management objectives and strategies.
\end{abstract}

Keywords: wildfire management, suppression effectiveness

\section{Introduction}

Wildfire management currently represents nearly 50 percent of the US Forest Service's (USFS) total budget. Suppression of large wildland fires represents the single largest outlay within wildfire management; currently the USFS consistently exceeds \$1 billion (US) annually in large fire suppression costs alone. In both 2012 and 2013 the Agency exceeded its large fire suppression budget allocation by over $\$ 400$ million. A majority of wildfire ignitions (96-98 percent) are captured during initial attack, or the first burning period with only a small percentage exceeding initial attack capability. Although these escaped fires constitute a small portion of the total number of fires, they account for the majority of the suppression expenditures of all wildfire management activities (Calkin et al. 2005). Despite the scale of the investment in large wildfire suppression, relatively little is understood about how suppression actions influence large wildfire spread and those conditions that ultimately lead to containment (Finney et al., 2009). Wildfire containment under initial attack (IA) has typically been 
modelled by evaluating the elliptical rate of spread of an ignition under identified fuel and weather conditions compared with the productive capacity and arrival time of IA resources (see for example Fried and Fried, 1996). However, the large fire environment presents additional complexity and it has not been demonstrated if the IA containment approach is relevant to large wildfire suppression. There is considerable uncertainty in managing large wildfires including the quality of weather forecasts, complex environmental conditions, variation in the type and quality of suppression resources, and whether or not requested suppression resources will be assigned (Thompson and Calkin, 2011). Additionally, many resources are engaged in non-line building activities such as point protection, contingency line development and mop-up. Further, given that the wildfire escaped IA it is likely that the characteristics of wildfire growth are such that line building efforts may not be feasible or effective.

Data necessary to understand suppression effectiveness within the US can be difficult to obtain. Some recent studies have relied on primary reporting systems such as the ICS-209 Situation report. However, these data do not provide spatial characteristics of the fire environment and rely on self-reporting by the incident team responsible for managing the events. In particular some of the most relevant data for suppression modelling contained within the ICS 209; specifically percentage of the wildfire contained, growth potential, and reported values at risk are subjective and may not be accurately reported (Holmes and Calkin, 2013). Despite these challenges several authors have examined the 209 data to model suppression effectiveness

Finney et al (2009) modelled the probability that on a given day a large fire would be declared fully contained by examining wildfire suppression resource assignment, daily fire growth, fuel model and other reported data within the 209 reports. The most significant finding to achieving wildfire containment was the critical importance of quiescent periods during the fire. That is, the most important factors in determining if a wildfire was fully contained were the number of low growth fire days and the number of previous intervals of low growth. Containment probability was negatively related to the presence of timber fuel types. No significant relationship was found between likelihood of containment and fire size or number of personnel assigned.

Holmes and Calkin (2013) utilized similar data from the ICS 209 to examine the relative efficiency of suppression resources by comparing published resource line building production rates published by Broyles (2011) with daily line built estimated from reported fire size and percentage containment. The results indicated that the actual production rates of suppression resources on a set of large wildland fires in 2009 were between 14 to $93 \%$ of the reported standard production rates. Further, the econometric models indicated that the marginal productivity of all inputs increased as total resources assigned increased. This result may indicate economies of scale in fire suppression or, alternatively, that fire managers learn how resources may be deployed more productively over the course of a fire.

In this paper we evaluate recent efforts to better understand the effectiveness of suppression resources in containing large fires. Given results from recent and current studies we identify potential opportunities for future research efforts that will allow us to better understand the implications of the existing research and improve the effectiveness of future large wildfire management.

\section{Methods}

We examine fireline productivity and suppression effectiveness for large wildland fire suppression activities as fire progresses using geospatial perimeter data. We estimate suppression effectiveness using stochastic frontier analysis. We modelled wildfire containment as a production process where crews are resources are assigned to build fireline until the amount of built fireline along the final fire perimeter equals the current fire perimeter. Production of controlled fireline on a particular fire day is the final output of the daily production operation. A mixture of resources are engaged in a large wildland fire suppression operation, and the production of controlled fireline depends on combination 
of these major inputs (e.g. crews, dozer, engines, helicopter and air tanker). The ability of a production unit to transform inputs into corresponding outputs is affected not only by the combination of major inputs but also by exogenous environmental factors. We include these weather and landscape related variables on the right hand side of the frontier production function as the inefficiency effects component of our model to capture effect of these characteristics on productivity and suppression effectiveness.

\section{Results}

The coefficient of all suppression resource input variables are significant and as of the expected direction of a priori assumptions with the exception of a negative and significant coefficient for ground crew resources. That is the presence of additional ground crews results in a reduction in held fireline for that day. Estimates from the inefficiency effect model provide the direction of the influence of the corresponding variables to efficiency. However, these coefficients do not provide magnitude of the effect and cannot be interpreted reasonably.

Results from the marginal effects of inefficiency model indicate that efficiency increases if firelines are built along the natural break see table 1 . However, marginal effects are fairly small. Previous fires seem to play a significant role in increasing efficiency of controllable fireline production. Again, marginal effects are fairly small. Relative day seems to be one of the strongest factors that influence efficiency. Every one day increase fire days increases the efficiency by about 7 percentage points suggesting that contained fireline increases over time possibly due to learning how best to engage the fire with improved suppression strategies and tactics. Efficiency gain is highest on those fires where full suppression is identified as the preferred strategy.

Table 1. Marginal Effect of specified variables on daily fireline produced.

\begin{tabular}{cc} 
Variable & Marginal Effect \\
\hline max_gust_- & 0.04556 \\
max_rh_lag & -0.05212 \\
timber & 1.021 \\
rivers & 0.1074 \\
roads & 0.01456 \\
full_suppress & 2.646 \\
previous _fire & 0.07543 \\
relative_days & 7.151
\end{tabular}

Most interesting, our results indicated that the number of assigned crews is not significantly related to the amount of permanently controlled fireline. This is most likely related to our definition of the objective of suppression efforts. Our definition of the suppression objective is to produce controlled fireline on a given day that ultimately is along the final fire perimeter. It should be noted that it does not include any fireline that may have been produced, but ultimately burned over, nor any built fireline such as contingency lines that never engage the fire. Further, on many fires strategies may include significant effort on burn out operations. In these circumstance significant resource effort is assigned to construct indirect line over several days that is ultimately burned out. This results in all of the effects of the effort being recognized on a single operational day when the burnout was conducted. Additionally, on many fires significant suppression effort is assigned to assure that controlled fireline along already burned areas does not reignite by "mopping up" any burning material within the fire's interior. 
In a related effort we collected field based data for a small set of individual large fires that provide the ability to link the specific assignment of all ground suppression crews assigned to the fire. Results from this small sample of large fires demonstrate that only 22 percent of all ground crew assignments were related to direct line building missions whereas approximately 60 percent of all assignments were related to indirect line building, holding, or mopping up a fire.

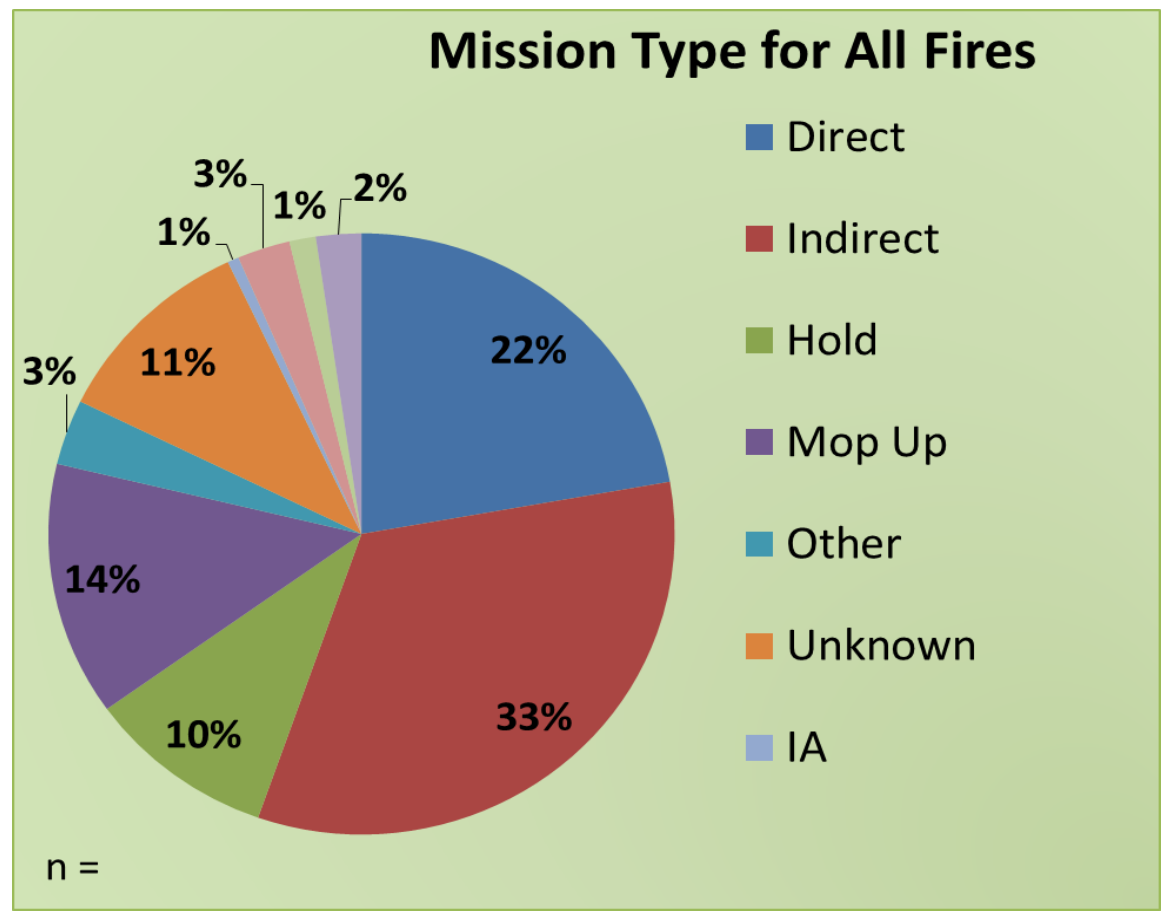

Figure 1. Ground crew mission type for 5 large US Forest Service Fires

The fire environment is the most important factor that can determine the success or failure of suppression effort. Obviously, fire managers have no control over topographic or weather elements. There could be several other variables that influence fire behaviour and efficiency of fireline production but are not included in our analysis. With these caveats in mind, our results suggest that production of controllable fire line is more efficient if they are built along the natural lines such as rivers and roads. However, these effects are only marginally significant and fairly small. Similarly, if there are areas that were burnt by previous fires, it is more efficient to construct the controllable fireline. Thus, efficiency analysis provides useful information in that it identifies the circumstances under which the suppression effort (as defined in this analysis) is more efficient

\section{Discussion}

These results collectively call for a re-evaluation of how we model the effectiveness of wildfire suppression actions and the productivity of individual resource categories assigned to large wildland fires. Uncertainty around fire progression, weather, and individual resource effectiveness make developing wildfire suppression strategies extremely challenging. Improving our understanding of how resources contribute to reducing wildfire related losses is critical to improving the safety, effectiveness, and efficiency of large wildfire management.

\section{References}

Broyles, G., 2011. Fireline production rate. USDA Forest Service, National Technology \& Development Program, Fire Management Report 1151-1805, San Dimas, CA. 
Calkin, D.E., K.M. Gebert, J.G. Jones, and R.P. Neilson. 2005. Forest Service Large Fire Area Burned and Suppression Expenditure Trends, 1970-2002. Journal of Forestry. 103(4): 179-183.

Finney, M., Grenfell, I.C., McHugh, C.W., 2009. Modeling containment of large wildfires using generalized linear mixed-model analysis. Forest Science 55, 249-255.

Fried, J.S. and B.D. Fried. 1996. Simulating wildfire containment with realistic tactics. Forest Science. 42: 267-281.

Holmes, T.P., Calkin, D.E., 2013. Econometric analysis of fire suppression production functions for large wildland fires. International journal of wildland fire 22, 246-255.

Thompson, M.P. and D.E. Calkin. 2011. Uncertainty and risk in wildland fire management: A review. Journal of Environmental Management. 92: 1895-1909. 